\title{
Biopsychosocial characteristics of sex offenders: An analysis of legal proceedings
}

\section{Características biopsicossociais de autores de agressão sexual de crianças/adolescentes: uma análise de processos jurídicos}

\author{
Daniela Castro dos REIS' ${ }^{1}$ (D) 0000-0002-9505-4516 \\ Lília lêda Chaves CAVALCANTE² (1) 0000-0003-3154-0651 \\ Mário Diego Rocha VALENTE³ (10) 0000-0001-7262-3336
}

\begin{abstract}
In this research, biopsychosocial characteristics of people accused of sexual aggression against children/adolescents between 2012 and 2014, in three districts of the state of Pará, were identified and analyzed. Data were collected by consulting court cases and recorded on a form prepared by the research group for biopsychosocial characterization. The statistical treatment of the data involved the non-hierarchical k-means clustering method, with cluster analysis. The results revealed three distinct groups; some with certain similarities due to the biological characteristics observed (Afro-descendant men over the age of 30 years, without reported organic diseases), as well as psychological and social characteristics (men with defined occupation and work, living in urban areas, with aggression to the black victim and in the family context) and differences (schooling, alcohol abuse and physical or psychological aggression, victim sex and family attachment to the aggressor). Further studies may refine the preliminary conclusions of these analyses.
\end{abstract}

Keywords: Adolescent; Child; Sex offenses.

$\boldsymbol{M r}$

1 Universidade Federal Rural da Amazônia, Curso de Administração. Campus Parauapebas, Rod. PA 257, Km 13, 68515-000, Parauapebas, PA, Brasil. Correspondência para/Correspondence to: D.C. REIS. E-mail: <danireispara@yahoo.com.br>.

${ }^{2}$ Universidade Federal do Pará, Núcleo de Teoria e Pesquisa do Comportamento, Programa de Pós-Graduação em Teoria e Pesquisa do Comportamento. Belém, PA, Brasil.

3 Departamento de Trânsito do Pará, Núcleo Pedagógico, Setor Educacional. Belém, PA, Brasil. Support: Conselho Nacional de Desenvolvimento Científico e Tecnológico (grant $n^{\circ}$ 472002/2014-7).

Article based on the master's thesis of D.C. REIS, entitled "Autores de agressão sexual de criança e adolescente: características biopsicossociais e trajetória de vida”. Universidade Federal do Pará, 2016.

Como citar este artigo/How to cite this article

Reis, D. C., Cavalcante, L. I. C., \& Valente M. D. R. (2019). Biopsychosocial characteristics of sex offenders: An analysis of legal proceedings. Estudos de Psicologia (Campinas), 36, e170165. http://dx.doi.org/10.1590/1982-0275201936e170165 


\section{Resumo}

Nesta pesquisa, identificaram-se e analisaram-se características biopsicossociais de pessoas acusadas de agressão sexual contra criança/adolescente, entre 2012 e 2014, em três comarcas do estado do Pará. Os dados foram coletados por meio de consulta aos autos de processos jurídicos, e registrados em formulário para caracterização biopsicossocial elaborado pelo grupo de pesquisa. O tratamento estatístico dos dados envolveu o método de agrupamento não hierárquico k-médias, com análise de Cluster. Os resultados identificaram três grupos distintos, mas que possuíam certa similaridade em razão das características biológicas neles observadas (homens negros com mais de 30 anos, sem doenças orgânicas), assim como características psicológicas e sociais (homens com ocupação e trabalho definidos, residentes em área urbana, com agressão à vítima negra e no contexto familiar) e diferenças (escolaridade, abuso de álcool e prática de agressão física ou psicológica, sexo da vítima e vínculo familiar com o agressor). Novos estudos podem refinar as conclusões preliminares destas análises.

Palavras-chave: Adolescente; Criança; Delitos sexuais.

Scientific findings (Lasher \& McGrath, 2017; Rodrigues, 2017) emphasize that the biopsychosocial characteristics of sex offenders against children/adolescents may present both similar and different characteristics. These characteristics may demonstrate that there are patterns in this population that must be understood and studied, particularly in Brazil, where this type of research is still incipient.

Despite the evident importance in identifying the biopsychosocial characteristics of sex offenders against children/adolescents, studies have endeavored to analyze these characteristics. In this sense, to better understand the diversity that seems to characterize this population, scholars have searched for characteristics that may be distinct in certain groups of sex offenders against children/adolescents (offenders with a preference for children, those who target adolescents, or offenders with sexual deviance, among others). Thus, identifying the diversity of these characteristic patterns, similarities, and tendencies increases the explanatory power of this complex phenomenon and helps develop consistent strategies (Lasher \& McGrath, 2017; Pincolini \& Hutz, 2014).

Although studies have suggested a heterogeneity of the so-called sex offenders against children/adolescents, recent studies (Miller, 2013; Mogavero \& Hsu, 2017) have indicated there are similar characteristics, seeking to identify the existence of a set of attributes capable of distinguishing them from other groups of criminals (sexual offenders against adults, for example). This has inspired further research on patterns and has opened new lines of research in this field.

Among the studies, the main biopsychosocial characteristics found in the literature are related to the biological particularities, such as physiological arousal, age, sex (Pincolini \& Hutz, 2014; Shelton, Eakin, Hoffer, Muirhead, \& Owens, 2016; Sullivan \& Sheehan, 2016; Titcomb, Goodman-Delahunty, \& Puiseau, 2012), psychological traits, with emphasis on self-esteem, alcohol and/or drug abuse, attachment style and cognitive distortion (Levenson \& Socia, 2016; Walton, Duff, \& Chou, 2017; Wurtele, Simons, \& Moreno, 2014), and social conditions, such as dysfunctional family dynamics, kinship relationship, age and gender of the victim (Shelton et al., 2016, Titcomb et al., 2012).

Among the biological characteristics related to sex offenders against children/adolescents, physiological excitation is outstanding. Despite its importance, this characteristic is not consensual among researchers, as argued by Marshall (2014) and Michaud and Proulx (2009), since these individuals are not always excited by the presence or image of a child or adolescent. Another biological characteristic reported in the studies on sexual offense is age. Several studies (Pincolini \& Hutz, 2014; Shelton et al., 2016; Sullivan \& Sheehan, 2016; Titcomb et al., 2012) have pointed out that this population generally belongs to the 30-50 years age group. Research conducted by Titcomb et al. (2012), which involved biological and non-biological parents (stepfathers), identified that the mean age of sex offenders against children/adolescents at first aggression

2 was 36.31 years $(S D=7.5)$, ranging from 20 and 68 years, in both samples. 
Another biological characteristic in the literature is the gender of sex offenders against children/ adolescents. Studies such as those published by Levenson and Socia (2016) and Sullivan and Sheehan (2016) report that sex offenders against children/adolescents were exclusively or mostly male. Other studies conducted by Colson, Boyer, Baumstarck, and Loundou (2013), Costa (2011), and Grattagliano et al. (2012) investigated female sexual offenders. However, it is difficult to reasonably estimate the exact number of individuals or the percentage of this population. Some experts believe that approximately $4 \%$ of sex offenders are women (Finkelhor \& Russell, 1984; Huss, 2011) and 95\% are men (Miller, 2013).

As for the psychological aspects, scientific studies point out that sex offenders against children/ adolescents may hold a negative view of women, presenting a series of myths about abuse. These individuals generally condemn the practice of violence, despite identifying themselves with the dominant male role (Lima, 2016). The sex offenders against children/adolescents may also present low self-esteem, psychoactive substance abuse problems, inability to manage feelings of anger, and dysfunctional mood (Lima, 2016). Miller's (2013) literature review argues that in terms of psychological characteristics, this population may suffer from loneliness and lack of intimacy, and sexual aggression can be used as a strategy to control people and reduce emotional loneliness.

In addition to these characteristics, another psychological attribute that plays a prominent role in research is the cognitive distortions of sex offenders against children/adolescents, that is, distorted thinking patterns that explain or justify their aggressive behavior. Studies on cognitive distortion have frequently suggested the presence of different thinking patterns in this population, which ranges from those who tend to deny the act to those who minimize aggression (Schneider \& Wright, 2001; Vanderstukken, Benbouriche, Pham, \& Lefebvre, 2015; Walton et al., 2017).

In the study by Nunes and Jung (2012), despite considering a large sample of participants (adult and child victims), the authors analyzed a set of secondary data to examine the degree of association between various measures of cognitive distortion and denial/minimization among sex offenders against children/adolescents (Sample 1, $n=73$; Sample 2, $n=42$; Sample 3, $n=38$ ), and rapists (Sample 1, $n=41$, Sample $3, n=14$ ). The study conducted a meta-analysis of the results of three samples of sex I offenders against children/adolescents that support the presence of cognitive distortions on sexual aggression, which, in general, were associated with greater denial/minimization of guilt and deviance $(r=0.24)$, injury to the victim $(r=0.32)$, need for treatment $(r=0.21)$ and responsibility for sexual aggression $(r=0.16)$.

Regarding the attributes related to social characteristics, scientific studies suggest that sex offenders against children/adolescents generally come from families with dysfunctional dynamics and inconsistent educational practices (Lima, 2016; Miller, 2013). In addition to these characteristics, others are frequently reported in the literature: the kinship relationship and gender of the victim (Miller, 2013; Titcomb et al., 2012), people who live with the victim, either in the family context or outside. In the research by Costa, Rocha, and Cavalcante (2018) and Santos et al. (2015), most sex offenders against children/adolescents have some degree of proximity to the victim, probably being relatives or people with whom they had a relationship with a certain level of confidence (e.g., nanny, teacher, trainer) and mostly female. The mean age of the victims was nine years and they almost always suffered multiple sexual abuses.

In a study conducted by Titcomb et al. (2012), data showed that most victims were female children $(91.1 \%)$, followed by males $(4.7 \%)$, and that $4.2 \%$ of sex offenders against children/adolescents abused individuals of both genders. In the study by Blasko, Jeglic, and Mercado (2011), although the study used a mixed sample (adult and child/adolescent victims), data also revealed that most sex offenders against children/adolescents committed sexual aggression against female victims ( $n=59.78 \%$ ), followed by male victims ( $n=15.20 \%)$, and two (2.0\%) against victims of both genders. 
As argued, some of these biological, psychological and social characteristics have been studied exclusively and/or interdependently. Among these characteristics, the following may be included: poor social competence, low self-esteem, feelings of inadequacy, feelings of vulnerability, difficulty in interpersonal relationships with adults, feeling of being physically unattractive, several problems related to sexual fulfillment, humiliation and Ioneliness (Schneider \& Wright, 2001; Vanderstukken et al., 2015; Walton et al., 2017).

The characterization of sex offenders against children/adolescents is not always a simple task, since these individuals are part of a group that have distinct trait characteristics (Costa et al., 2018; Lasher \& McGrath, 2017; Mogavero \& Hsu, 2017; Rodrigues, 2017; Schaaf, Jeglic, Calkins, Raymaekers, \& Leguizamo, 2016). Thus, there is a relative consensus among the researchers investigating the characteristics of sex offenders against children/adolescents that these attributes are heterogeneous and further research is required to investigate the characteristics of this population (Michaud \& Proulx, 2009; Schaaf et al., 2016), to plan public policies focused on developing methods for coping with sexual aggression to help child/adolescent victims.

Therefore, this study sought to identify and analyze the biopsychosocial characteristics of sex offenders against children/adolescents based on the records of the charges filed against sexual offenders against children and adolescents in the court of justice in three municipalities in the state of Pará between 2012 and 2014.

\section{Method}

This study used secondary data obtained from the examination of legal documents of criminal charges against sex offenders against children/adolescents, made available by legal institutions, which is, therefore, a documentary study.

\section{Research context}

The research involved three municipalities in the state of Pará in distinct courts (Belém, Abaetetuba and Parauapebas), which enabled a broad and regionalized analysis of data. This choice was made due to geopolitical criteria such as the political-administrative system of the municipality, but also because there are judicial districts with a history of violations against the rights of children and adolescents.

\section{Ethical considerations}

The research project was approved by the Núcleo de Medicina Tropical-NMT/Universidade Federal do Pará, issued on 04/30/2014, under registration $n^{\circ}$ 650.210. This research is in agreement with Resolution 510/16 of the National Health Council.

\section{Sample}

The study collected data from court cases involving male and female sexual offenders over the age of 18 years, who had been sentenced for the crime of sexual assault against children and adolescents between 2012 and 2014. The sample size took into account the number of cases found in each municipality by the Libra system. In Abaetetuba, 47 court cases were found, and the sample calculation indicated $n=17$. In Belém, 555 court cases were found, and 206 were selected. In Parauapeabas, 27 court cases were selected out of 73 cases. A total of 250 court cases were analyzed. For the analysis of the sample calculation, the data were

4 stratified, considering the court cases selected from each court of justice. 


\section{Instruments}

Form for biopsychosocial characterization of sex offenders against children/adolescents and the victim.

The form for the biopsychosocial characterization of sex offenders against children/adolescents and the victim was prepared by the research group and the aim was to collect: (a) identification data (seven items: form number, lawsuit, filing of the lawsuit, occurrence of first aggression, date of collection, researcher, city), (b) biopsychosocial data of sex offenders against children/adolescents and victim (34 items: age, gender, skin color/ethnicity, religion, marital status, children, among others); (c) court data of the defendant (20 items: neighborhood where the assault occurred, intrafamilial or extrafamilial aggression, confession, duration of the assault, sentence, among others), and (d) the victims (15 items: victim was a relative, types of aggression suffered, among others).

\section{Procedure}

The data collection, carried out by the Study of Sexual Child and Adolescent Aggression Authors (EASCA, Estudo dos Autores de Agressão Sexual de Criança e Adolescente) team in court archives, consisted of the collection of information of the legal proceedings and lasted approximately four months, from March to July 2014. For the analysis of the court cases, an information bank was organized and constantly updated by the members of the group; then the data were evaluated using cluster analysis and discriminating analysis.

The purpose of this analysis was to identify which group had or did not have certain characteristics, thus indicating a difference and similarity among the characteristics of the groups. Cluster analysis was used to evaluate the following variables: 76 variables related to sex offenders against children/adolescents (identification, sociodemographic data, court data) and 13 variables associated with the victims (age, gender, ethnicity/skin color, religion, age group, housing context, age of first assault, education level, family neglect, psychological, physical, institutional and patrimonial violence).

The non-hierarchical k-means clustering method consists of a procedure in which a given number of previously determined clusters is used to calculate points representing the centroids of these clusters and homogeneously distributed in accordance with the responses obtained from the questionnaires and heuristically moved to obtain static equilibrium (Hair, Black, Babin, Anderson, \& Tatham, 2005).

To determine how many clusters had to be created, the literature review and visual inspection of the (non-hierarchical) dendrogram method were followed. Solutions with $k=2, k=3$ and $k=4$ were simulated, with three clusters considered the most adequate solution. The count and/or means were compared among the individuals of the different groups and total sample. Thus, this procedure allowed to verify the existence of differences between the three groups of individuals in the variables analyzed.

The discriminant analysis was performed using the Statistical Package for Social Sciences (SPSS Inc., Chicago, Illinois, United States, version 20.0) to estimate the parameters of the discriminant functions and perform the statistical tests at a significance level of 0.05 .

\section{Results}

Cluster analysis revealed three large groups with different characteristics, consisting of Group 1 (G1) with 94 individuals, G2 with 92 individuals and G3 with 64 individuals. The data revealed the presence of three clusters, based on the criterion of greater or less similarity among the biopsychosocial characteristics found in the population studied. The groups are based on the descriptions of their characteristics. 
To confirm if the groups were reliable and coherent, the clusters were evaluated using a discriminant analysis with the purpose of showing how well the individuals were correctly grouped into three groups, as shown in Table 1.

The discriminant function of G1 indicated that $95.7 \%$ of the cases sampled were classified correctly. The discriminant function estimated for $\mathrm{G} 2$ allowed to classify correctly $96.7 \%$ of sex offenders against children/adolescents and the discriminant function of $\mathrm{G} 3$ was able to classify correctly $98.4 \%$ of sex offenders against children/adolescents, and the remaining $1.6 \%$ were allocated to $\mathrm{G} 2$. Cross-validation indicated that $94.5 \%$ of sex offenders against children/adolescents were classified correctly and showed that the results were close to the original solution, which validates the analysis. The result was that $95.0 \%$ of the observations were classified satisfactorily, that is, only six observations were misclassified.

Thus, Figure 1 shows the discrimination of the three sex offenders against children/adolescents groups with prominence for the centroids of each group, blue for Group 1, green for Group 2 and red for Group 3. The idea of group behavior is that similar variables are grouped into each group, as well as the different variables. Therefore, the groups were organized in a way that each member was clustered into the groups.

The other variables analyzed, which did not appear in the groups, were discarded in the discriminant analysis because they did not discriminate as well as those chosen, demonstrating that sexual aggression is not explained by a single factor, but rather by a set of indicators statistically and not randomly clustered. This means that the variables were not randomly associated, but associated by similarity with the variables, forming the subgroups of the total population.

In addition to the descriptive analysis of the clusters, a table with the data of the groups was prepared, comparing them with their biopsychosocial characteristics and showing the similarities or differences between the three groups (Table 2).

Table 1

Results of the classification of sex offender samples in legal proceedings in the Tribunal de Justiça do Estado do Pará (TJE-PA) from 2013 to 2015

\begin{tabular}{|c|c|c|c|c|}
\hline \multirow{2}{*}{ Groups of sexual aggressors } & \multicolumn{3}{|c|}{ Probability of belonging to the groups } & \multirow{2}{*}{ Total } \\
\hline & Group 1 & Group 2 & Group 3 & \\
\hline \multicolumn{5}{|l|}{ Original count ${ }^{1}$} \\
\hline \multicolumn{5}{|l|}{ Groups } \\
\hline Cluster 1 & 90 & 4 & 0 & 94 \\
\hline Cluster 2 & 1 & 89 & 2 & 92 \\
\hline Cluster 3 & 0 & 1 & 63 & 64 \\
\hline \multicolumn{5}{|l|}{$\%$} \\
\hline Cluster 1 & 95.7 & 4.3 & 0.0 & 100 \\
\hline Cluster 2 & 1.1 & 96.7 & 2.2 & 100 \\
\hline Cluster 3 & 0.0 & 1.6 & 98.4 & 100 \\
\hline \multicolumn{5}{|l|}{ Cross-validation count ${ }^{2}$} \\
\hline \multicolumn{5}{|l|}{ Groups } \\
\hline Cluster 1 & 90 & 4 & 0 & 94 \\
\hline Cluster 2 & 2 & 86 & 4 & 92 \\
\hline Cluster 3 & 3 & 2 & 59 & 64 \\
\hline \multicolumn{5}{|l|}{$\%$} \\
\hline Cluster 1 & 95.7 & 4.3 & 0.0 & 100 \\
\hline Cluster 2 & 2.2 & 93.5 & 4.3 & 100 \\
\hline Cluster 3 & 4.7 & 3.1 & 92.2 & 100 \\
\hline
\end{tabular}

Note: ${ }^{196.8 \%}$ of the cases in the original groups are correctly classified; ${ }^{2} 94.5 \%$ of the cases of the cross-validation groups are correctly classified.

6 Source: The authors. 


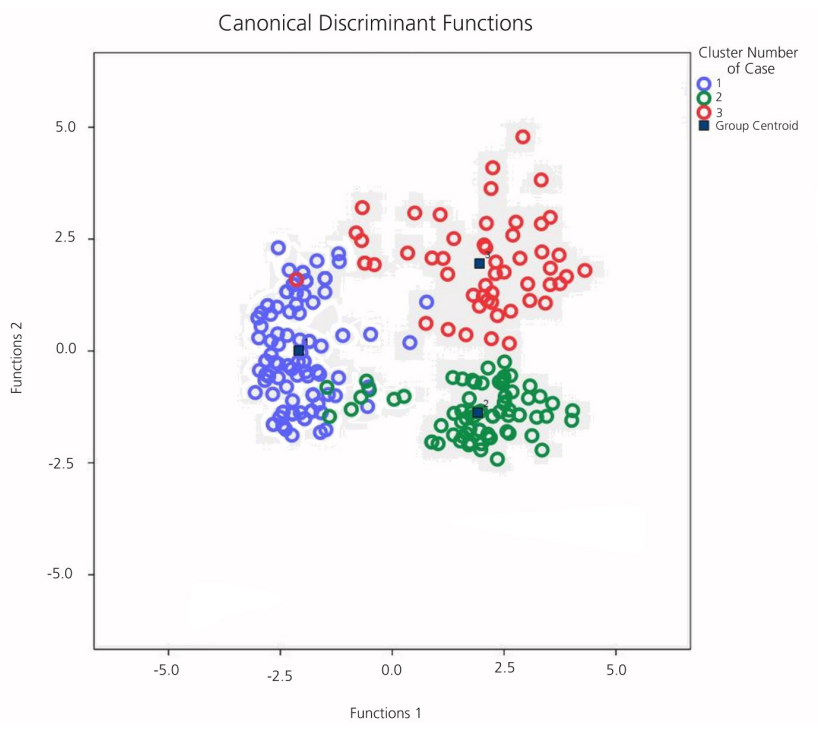

Figure 1. Discriminant map showing the groups of sex offenders against children/adolescents according to the legal proceedings in the Tribunal de Justiça do Estado do Pará (TJE-PA) from 2012 to 2014.

Source: the authors.

Table 2

Comparative diagram of the characteristics of the three clusters. Representation of symbols: characteristic belongs to the group (+); characteristic does not belong to the group (-); mixed characteristics present in the group (+/-)

\begin{tabular}{|c|c|c|c|}
\hline Biopsychosocial characteristics & G1 & $\mathrm{G} 2$ & G3 \\
\hline \multicolumn{4}{|l|}{ Biological characteristics } \\
\hline Male & + & + & + \\
\hline Over the age of 30 years & + & + & + \\
\hline Afro-descendent & + & + & + \\
\hline Without organic diseases & + & + & + \\
\hline Over the age of 30 years when committed $1^{\text {st }}$ sexual assault & + & + & $+/-$ \\
\hline \multicolumn{4}{|l|}{ Psychological characteristics } \\
\hline Alcohol abuse & $+/-$ & $+/-$ & + \\
\hline Aggressiveness & - & - & $+/-$ \\
\hline Psychological aggression & $+/-$ & - & + \\
\hline Physical aggression & - & - & $+/-$ \\
\hline Hand on & + & +- & + \\
\hline Denial of sexual assault & + & + & + \\
\hline \multicolumn{4}{|l|}{ Social characteristics } \\
\hline Female victims & $+/-$ & + & + \\
\hline Child victims & + & $+/-$ & - \\
\hline Afro-descendant victim & + & + & + \\
\hline Catholic victim & $+/-$ & $+/-$ & $+/-$ \\
\hline Intrafamilial bond & + & - & $+/-$ \\
\hline With spouse & + & $+/-$ & + \\
\hline With children & + & $+/-$ & + \\
\hline Catholic & + & + & +- \\
\hline Low education level & + & $+/-$ & - \\
\hline With occupation & + & + & + \\
\hline Employed & + & + & +- \\
\hline Urban residence & + & + & + \\
\hline Sexual assault was committed on the weekday & + & + & +- \\
\hline Agression occurred in a private context & + & + & + \\
\hline On parole & + & + & + \\
\hline No previous convictions & + & $+/-$ & + \\
\hline Access to alcoholic beverage & + & - & $+/-$ \\
\hline
\end{tabular}


The results showed that the biological characteristics of the groups showed homogeneity, that is, the individuals of the three groups showed some similarity when their biological characteristics were evaluated, since four out of five characteristics investigated were present in these groups.

As for the psychological characteristics, the data revealed heterogeneity when the groups were observed together, that is, the characteristics presented some important distinctions, since of the five characteristics analyzed, only one was observed in the three groups (denial of aggression). This aspect was also observed in the social characteristics, since five out of 17 characteristics investigated were assigned to the three groups, namely: ethnicity/skin color of the victim, occupation, urban residence, private context and on parole.

\section{Discussion}

The discussion of the results will be presented first considering the biological, psychological and social categories that presented similarities between the groups. Then the same categories will be discussed showing the differences between the three groups.

\section{Similarities between groups}

In this first discussion of the data, it is interesting to note that there are similarities in the biopsychosocial characteristics between the three groups. All members of the groups were men, aged over 30 years, and Afro-descendants.

The similarities among the biological characteristics may be related to specific characteristics of the information source from which the data was collected. In other words, the documents used as research sources that reveal homogeneity of the biological characteristics involving the sex offenders against children/ adolescents may be reflecting the proportion of these characteristics in the Brazilian population, or even represent the polarization that the Brazilian society has been experiencing since its period of colonization. Thus, society would be divided into two distinct groups of people, on one side the workers and on the other the criminals, usually Afro-descendants.

However, in macrosystemic terms, the justice system still reflects the segregation that the society experiences. The prison population is composed of young men with low income and education level, according to a national survey of penitentiary information (Ministério da Justiça e Segurança Pública, 2018), which reinforces ideologies that associate crime and violence with a population with low socioeconomic status. In general, cases that reach the justice system tend to involve individuals with low socioeconomic status (income, education level and occupation) and who generally have less access to socioeconomic and cultural opportunities.

Another aspect refers to the data on the predominance of males found in the records of legal proceedings. The research of this variable, although necessary, must be problematized. It is unclear why there is such a low number of cases involving female aggressors, but it may be due to a lower incidence of these cases or underreporting. This aspect still requires further investigation in the Brazilian scenario.

Another aspect is related to the age of the sex offenders against children/adolescents, men over the age of 30 years. In general, these findings are equivalent to the other studies analyzed. In the studies by Pincolini and Hutz (2014); Shelton et al. (2016); Sullivan and Sheehan (2016), and Titcomb et al. (2012), for example, there were no significant differences in the mean age among the participants, who were approximately 40 years old. In the study by Pincolini and Hutz (2014), at the time of the crime, they were around the age

8 of 40 years, although with great variation $(M=39.54, S D=13.76$ years). These two biological characteristics 
corroborate the findings of some studies that indicate that most sex offenders against children/adolescents are males over the age of 30 years (Levenson \& Socia, 2016; Sullivan \& Sheehan, 2016; Titcomb et al., 2012).

In addition to the biological characteristics of gender and age, data on Afro-descendants were identified in the results. The study by Schaaf et al. (2016) argues that given the ethno-racial diversity of the sexually aggressive population and the scarcity of available research on ethnicity and sexual aggression, it is imperative to assess whether this characteristic is present among sex offenders. However, few studies, such as those by Burton and Ginsberg (2012) and Wiederman, Manyard, and Fretz (1996), have examined ethnic and racial characteristics among sex offenders. An example was the study by Kirk (1975) who found that white sex offenders against children/adolescents tend to engage in more deviant behaviors than black sex offenders against children/adolescents.

Besides the biological category, another similarity was found in the psychological category. G1 and G2 presented similarities among the variables, such as alcohol abuse and absence of physical aggression during sexual aggression. Regarding alcohol abuse, as reported in the study by Titcomb et al. (2012), sexual offenders against children/adolescents have been divided into two groups: those who have knowledge about the abusive use of psychoactive substances, such as licit and illicit drugs, and those who do not. In the first group, approximately one third of the research participants who had been instructed on drug abuse did not present a history of alcohol or drug abuse (34.6\%). In the second group (34.6\%), who had not been instructed on drug abuse, presented a history of alcohol or drug abuse.

The denial of aggression was another psychological characteristic that was similar between the three groups (G1, G2 and G3), that is, all the individuals in the groups denied having committed sexual aggression. The studies on the cognition of sex offenders against children/adolescents have indicated the presence of several cognitive distortions in this population, ranging from those who tend to deny the act to those who deny and/or minimize the act (Schneider \& Wright, 2001; Vanderstukken et al., 2015; Walton et al., 2017).

In the discussion of the data on the similarities of the groups in the social category, the results revealed the following situation: G1, G2 and G3 are similar when related to the skin color of the victim, occupation, urban residence, sexual aggression committed in a private context, and being on parole. The similarity related to the gender of the victim (female) was observed in $G 2$ and $G 3$, and in $G 1$ the victims were both female and male. Santos et al. (2015) identified that most sex offenders against children/adolescents reported that their victims were women from the extrafamilial context. Several authors point to the predominance of female victims (Levenson \& Socia, 2015; Pincolini \& Hutz, 2014; Shelton et al., 2016). The data contradict ideas that rest on the social imaginary that the family environment is a safe place, and that the aggressor does not belong to the private context.

Another similarity identified in G1 and G3 is related to the variable marital relationship and presence of children, pointing out that individuals in these groups had spouses and children. As for G2, this group presented mixed characteristics, that is, individuals with or without spouses and children. In G1 and G2, similar variables were associated with the catholic religion and labor activity, that is, the individuals in this group were working at the time of the assault and sexual aggression occurred on a weekday. Thus, perpetrators of sexual aggression are generally working individuals, who have spouses and children, revealing the profile of a typically nuclear (or traditional) family and heterosexual.

In the study by Shelton et al. (2016) who conducted an investigative analysis of sex offenders against children/adolescents and their aggressive behaviors, $43 \%(n=83)$ of sex offenders against children/adolescents had never been married; $34 \%(n=66)$ were married; $12 \%(n=24)$ were divorced; $5 \%(n=9)$ were separated; $2 \%(n=3)$ were widowers; $2 \%(n=3)$ were in a stable relationship and $2 \%(n=3)$ were classified as another. Regarding the family composition, $72 \%(n=151)$ lived with another person. Of the sex offenders against children/adolescents who lived with another person, 34\% $(n=52)$ lived with children under 18, but it was not specified whether they were biological children or not. 
Still in the study by Shelton et al. (2016), data on their employment history data revealed that $86 \%$ of the sex offenders against children/adolescents $(n=215)$ had a job history and 19\% $(n=41)$ of sex offenders against children/adolescents were employed in positions of trust (Education, Public Safety, Mental Health, Clergy, Medicine and a job in the category and child care provider). The remaining 3\% (7) did not work, $44(21 \%)$ worked in companies, 41 (19\%) worked with information technology, 36 (10\%) worked in the area of trade and construction and the remaining $28 \%$ in other job positions.

\section{Differences between groups}

In the biological category there was only one distinction among the data: the biological difference related to $\mathrm{G} 3$ and the age variable in which the accused/sentenced committed the first sexual assault. In this group in particular, both younger and older sex offenders against children/adolescents were identified when age of the first sexual assault was assessed.

The results also showed differences between the three groups in the analysis of the psychological category. The variable psychological aggression during sexual aggression was different in the three groups. This variable indicates that it must be investigated in depth, since its presence may be related to the severity of the aggression against the victim. Within this scenario, the results revealed that individuals in G1 committed and did not commit psychological aggression during sexual aggression; in G2, aggressions occurred without psychological aggression; and in G3, psychological aggression was committed during the sexual assault.

As for the results of the social category, four variables presented a distinction in relation to the three groups: the age of the victim, kinship relationship, education level and access to alcoholic beverages: G1 consisted of individuals with elementary education who preferred children with some degree of kinship and had access to alcoholic beverages; G2 consisted of individuals with primary, high school and higher education, the victims were children and adolescents, without family ties and no access to alcoholic beverages; the G3 presented the following characteristics: high school and higher education, preference for adolescent victims, with or without family ties, with or without access to alcoholic beverages.

As the literature suggests (Wurtele et al., 2014), some characteristics are similar, while others are different in the most diverse societies where studies have been conducted; therefore, further research is necessary if we want to know how heterogeneous this population is indeed. However, as Costa et al. (2018) and Pincolini and Hutz (2014) point out, the lack of national studies on the subject makes it difficult to know how much of the data reflect the Brazilian reality, and it is possible to question whether the characteristics are more similar than they are different.

A characteristic that is a different in the three groups is the educational level of the sex offenders against children/adolescents. In the study by Shelton et al. (2016) in the US, the information about the level of education of $43.0 \%$ of the sex offenders against children/adolescents was available $(n=107)$. Regarding the information available, $7.0 \%(n=7)$ had incomplete high school education; $22.0 \%(n=23)$ graduated high school or obtained the general equivalency diploma; $37.0 \%(n=40)$ attended college; $22.0 \%(n=23)$ had higher education; $2.0 \%(n=2)$ had graduate studies and $11.0 \%(n=12)$ had graduate degrees. In general, $72.0 \%(n=77)$ of the participants had some education. Data by Santos et al. (2015) sex offenders against children/adolescents that of a total of 409 participants in Brazil, 307 (78.1\%) had elementary education, $102(24.9 \%)$ had high school education.

As for access to alcohol, Titcomb et al. (2012) analyzed 136 cases of sex offenders against children/ adolescents that reported information on substance abuse, of which little more than a third had no history of alcohol or drug abuse (34.6\%), and a similar proportion had a history of substance abuse. In this same study, alcohol and drug abuse was associated with sexual aggression in one-third of the sample surveyed. 
However, Wurtele et al. (2014), emphasize in the conclusion of their study that the results support the specialist model (demonstrating an association of sexual experiences in childhood, including abuse) and the generalist model, which states that sex offenders against children/adolescents participate in a wide range of antisocial activities, have low self-control and impulsive behavior, such as alcohol abuse, unprotected sex and reckless driving. These conclusions reveal that the alcohol abuse or access can be an independent variable of the crime.

In general, considering only the biological characteristics, the three groups appear to be homogeneous (they present more similarities than differences among them): older Afro-descendant adult men, without psychic and organic diseases. In terms of psychological and social categories, the three groups presented similarities and differences. Thus, the three groups presented typical characteristics: G1 predominantly consisted of older Afro-descendant men, with a low level of education, Catholics, who committed or did not commit psychological aggression during the sexual assault and had preference for children and kinship relationship. G2 consisted of older Afro-descendant men, who did not commit psychological aggression during the sexual assault, had preference for children and adolescents, without kinship and with high and low education level. G3 mainly consisted of older Afro-descendant men, with a high level of education, who committed psychological aggression during the sexual assault and had preference for adolescents.

In general, sex offenders against children/adolescents are workers, who usually have a socially recognized occupation and the aggression occurred in the private context, which contradicts the social imaginary that suggests that society is divided into two distinct groups of people, workers and criminals, and that the family environment is a safe place against sexual violence.

Therefore, in theoretical terms, the aim of this study was to discuss the specificities of the characteristics of sex offenders against children/adolescents from a theoretical perspective; it is understood that these variables cannot be studied in isolation, that is, these variables must be studied within their specificities, but they can be interpreted in the general using the characterization proposed. Only research that studies these characteristics from a perspective of totality can understand the heterogeneity that defines this population today.

In spite of the contributions expected to be made, research on the characteristics of sex offenders against children/adolescents has limitations: insufficient or superficial information in the documents collected, but, above all, the psychological characteristics of sex offenders against children/adolescents, which may indicate problems of generalization, pointing out that further studies must be carried out using different sources of information; the general issues related to the underreporting of sex crimes lead to a typically common problems related to the research of the characteristics of sex offenders against children/adolescents, i.e., absence of a Brazilian matrix to study the sex offenders against children/adolescents, which limits the achievement of significant differences between the research groups and comparisons.

Researchers should be encouraged and supported to conduct studies using assessment tools that may contribute to identifying or mapping the characteristics of sex offenders against children/adolescents in a given social and cultural context.

\section{Contributors}

D.C. REIS contributed to the design, drawing, writing and analysis. L.I.C. CAVALCANTE contributed in writing, analyzing and discussing the results. M.D.R. VALENTE contributed in the writing of the article and the analysis of the results, helping to systematize them. 


\section{References}

Blasko, B. L., Jeglic, E. L., \& Mercado, C. C. (2011). Are actuarial risk data used to make determinations of sex offender risk classification? An examination of sex offenders selected for enhanced registration and notification. International Journal of Offender Therapy and Comparative Criminology, 55(5), 676-692. http://dx.doi.org/10.1177/0306624X10372784

Burton, D. L., \& Ginsberg, D. (2012). An exploration of racial differences in deviant sexual interests among male adolescent sexual offenders. Journal of Forensic Social Work, 2, 25-44. http://dx.doi.org/10.1080/1936928X.2011.609766

Colson, M. H., Boyer, L., Baumstarck, K., \& Loundou, A. D. (2013). Female sex offenders: A challenge to certain paradigmsMeta-analysis. Sexologies, 22(4), 109-117. http://dx.doi.org/10.1016/j.sexol.2013.05.002

Costa, C. F. P. (2011). Abuso cometido por mulheres: um estudo de caso (Dissertação de mestrado nãopublicada). Universidade Fernando Pessoa, Porto. Recuperada em setembro, 5, 2016, de http://bdigital.ufp.pt/ bitstream/10284/3264/3/DM_15500.pdf

Costa, L. P., Rocha, C. J. B., \& Cavalcante, L. I. C. (2018). Características biopsicossociais entre acusados de agressão sexual contra crianças/adolescentes em contextos intra e extrafamiliar. Temas em Psicologia, 26(1), 283-295. http:// dx.doi.org/10.9788/TP2018.1-11Pt

Finkelhor, D., \& Russell, D. (1984). Women as perpetrators: Review of the evidence. In D. Finkelhor (Ed.), Child sexual abuse: New theory and research (pp.171-187). New York: Free Press.

Grattagliano, I., Owens, J. N., Morton, R. J., Campobasso, C. P., Carabellese, F., \& Catanesi, R. (2012). Female sexual offenders: Five Italian studies. Aggression and Violent Behavior, 17(3), 180-187. http://dx.doi.org/10.1016/j. avb.2012.01.001

Hair, J. F. Jr., Black, W. C., Babin, B. J., Anderson, R. R., \& Tatham, A. R. L. (2005). Análise multivariada de dados. Porto Alegre: Bookman.

Huss, M. T. (2011). Psicologia forense: pesquisa, prática clínica e aplicações. Porto Alegre: Artmed.

Kirk, S. A. (1975). The sex offenses of blacks and whites. Archives of Sexual Behavior, 4(3), 295-301.

Lasher, M., \& McGrath, R. J. (2017). Desistance from sexual and other violent offending among child sexual abusers. Criminal Justice and Behavior, 44(3), 416-431. http://dx.doi.org/10.1177/0093854816670194

Levenson, J. S., \& Socia, K. M. (2016). Adverse childhood experiences and arrest patterns in a sample of sexual offenders. Journal of Interpersonal Violence, 31(10), 1883-1911. http://dx.doi.org/10.1177/0886260515570751

Lima, A. C. S. (2016). Levantamento das possíveis variáveis envolvidas no comportamento de abusar sexualmente de crianças e adolescentes (Dissertação de mestrado não-publicada). Universidade Estadual de Londrina. Recuperado em fevereiro 10, 2016, de https://www.researchgate.net/profile/alex_gallo/publication/311675181_levantamento_ das_possiveis_variaveis_envolvidas_no_comportamento_de_abusar_sexualmente_de_criancas_e_adolescentes/ links/5853c9bf08aef7d030a7681f/levantamento-das-possiveis-variaveis-envolvidas-no-comportamento-de-abusarsexualmente-de-criancas-e-adolescentes.pdf

Marshall, W. L. (2014). Phallometric assessments of sexual interests: An update. Current Psychiatry Reports, 16(1), 1-7. http://dx.doi.org/10.1007/s11920-013-0428-6

Michaud, P., \& Proulx, J. (2009). Penile-response profiles of sexual aggressors during phallometric testing. Sexual Abuse: A Journal of Research and Treatment, 21(3), 308-334. http://dx.doi.org/10.1177/1079063209342073

Miller, L. (2013). Sexual offenses against children: Patterns and motives. Aggression and Violent Behavior, 18(5), 506519. http://dx.doi.org/10.1016/j.avb.2013.07.006

Ministério da Justiça e Segurança Pública. (Brasil). (2018). Levantamento Nacional de Informações Penitenciárias. Recuperado em agosto 23, 2016, de http://depen.gov.br/DEPEN/noticias-1/noticias/sisdepen-informacoespenitenciarias-consolidarao-base-de-dados-nacional

Mogavero, M. C., \& Hsu, K. (2017). Sex offender mobility: An application of crime pattern theory among child sex offenders. Sexual Abuse: A Journal of Research and Treatment, 2, 1-24. http://dx.doi.org/10.1177/1079063217712219

Nunes, K. L., \& Jung, S. (2012). Are cognitive distortions associated with denial and minimization among sex offenders? Sexual Abuse: A Journal of Research and Treatment, 25(2), 166-188. http://dx.doi.org/10.1177/1079063212453941

Pincolini, A. M. F., \& Hutz, C. S. (2014). Abusadores sexuais adultos e adolescentes no sul do Brasil: pesquisa em denúncias e sentenças judiciais. Temas em Psicologia, 22(2), 301-311. http://dx.doi.org/10.9788/TP2014.2-03

Rodrigues, R. C. (2017). Caracterização psicopatológica dos abusadores sexuais de menores intra versus extrafamiliares (Tese de Doutorado). Recuperado em outubro 2, 2016, de http://recil.grupolusofona.pt/jspui/handle/10437/8283 
Santos, C. A., Costa, M. C. O., Amaral, M. T. R., Sobrinho, C. L. N., Musse, J. O., \& Costa, A. M. (2015). Agressor sexual de crianças e adolescentes: análise de situações relacionadas à violação e vítimas. Adolescente e Saúde, 12(3), 7-20.

Schaaf, S., Jeglic, E. L., Calkins, C., Raymaekers, L., \& Leguizamo, A. (2016). Examining ethno-racial related differences in child molester typology: An MTC: CM3 approach. Journal of Interpersonal Violence, 9, 1-20. http://dx.doi. org/10.1177/0886260516653550

Schneider, S. L., \& Wright, R. C. (2001). The FoSOD: A measurement tool for reconceptualizing the role of denial in child molesters. Journal of Interpersonal Violence, 16, 545-564. http://dx.doi.org/10.1177/088626001016006004

Shelton, J., Eakin, J., Hoffer, T., Muirhead, Y., \& Owens, J. (2016). Online child sexual exploitation: An investigative analysis of offender characteristics and offending behavior. Aggression and Violent Behavior, 30, 15-23. http://dx.doi. org/10.1016/j.avb.2016.07.002

Sullivan, J., \& Sheehan, V. (2016). What motivates sexual abusers of children? A qualitative examination of the spiral of sexual abuse. Aggression and Violent Behavior, 30, 76-87. http://dx.doi.org/10.1016/j.avb.2016.06.015

Titcomb, C., Goodman-Delahunty, J., \& Puiseau, B. W. (2012). Pretrial diversion for intrafamilial child sexual offending does biological paternity matter? Criminal Justice and Behavior, 39(4), 552-570. http://dx.doi. org/10.1177/0093854811433678

Vanderstukken, O., Benbouriche, M., Pham, T. H., \& Lefebvre, L. (2015). Les distorsions cognitives des auteurs d'agression sexuelle d'enfant: Définitions, fonctions, et enjeux théoriques. Journal de Thérapie Comportementale et Cognitive, 25, 29-34. http://dx.doi.org/10.1016/j.jtcc.2014.11.001

Walton, J., Duff, S., \& Chou, S. (2017). A brief discussion about measuring child molester cognition with the sex with children scale. Child Abuse Review, 26, 91-102. http://dx.doi.org/10.1002/car.2361

Wiederman, M. W., Manyard, C., \& Fretz, A. (1996). Ethnicity in 25 years of published sexuality research: 1971-1995. The Journal of Sex Research, 33(4), 339-342.

Wurtele, S. K., Simons, D., \& Moreno, T. (2014). Sexual interest in children among an online sample of men and women: Prevalence and correlates. Sexual Abuse: A Journal of Research and Treatment, 26(6), 546-568. http://dx.doi. org/1079063213503688

Received: October 18, 2017

Final version: November 12, 2018

Approved: November 13, 2018 